\title{
Necrotic and apoptotic changes of neutrophils and mononocytes of blood in experimental periodontitis and their corrections by quercetin
}

\author{
A.Ye. Demkovych \\ SHEI “I. Horbachevsky Ternopil State Medical University”; e-mail: demkovushae@tdmu.edu.ua
}

\begin{abstract}
The purpose of the study was to determine the content of apoptotic-altered and necrotized mononuclear phagocytes and neutrophilic granulocytes in the development of experimental bacterial-immune periodontitis and its correction with quercetin (corvitin). The article presents the results of early and late apoptosis of the blood monocytes and neutrophils on the $14^{\text {th }}$ day of the inflammatory process development in periodontal tissues, as well as the possibility of theirs correction by quercetin. The blood monocytes and neutrophils were isolated by the method of gradient centrifugation. The evaluation of apoptosis and necrosis was performed by flow laser cytometry. The characteristic dynamics of dead cells was revealed in the process of the inflammatory formation in the periodontal complex. In particular, the course of experimental periodontitis was accompanied by an increase of annexinpositive (early apoptosis) blood monocytes and neutrophils on the $14^{\text {th }}$ day that corresponded to maximum intensification of the inflammatory process and formation response to antigen stimulation. The indices of late apoptosis / necrosis during this period also exceeded the control values. The quercetin (intramuscularly in a dose of $100 \mathrm{mg} / \mathrm{kg}$ ) reduced number of blood mononuclear phagocytes and neutrophilic granulocytes with signs of death cell and improved the course of the inflammatory process.
\end{abstract}

Key words: bacterial-immune periodontitis; mononuclear phagocytes; neutrophilic granulocytes; apoptosis; necrosis; quercetin.

\section{INTRODUCTION}

Etiology and pathogenesis of periodontal disease are completed, insufficiently investigated and is formed one of important problems of theoretical and practical medicine [1]. The main role in this belong to the infectious factors and activity of immune system (local cellular nonspecific and general adaptive) to form an adequate character of development and course of the pathological process in the oral cavity. The effectiveness of therapeutic effects and preventive measures depends from this [2]. Among the wide spread diseases connected with periodontal complex is periodontitis, in particular its generalized form, in which inflammatory-dystrophic processes include all its tissues [3, 4]. The mechanisms owing to which local and general factors, differed by nature and character, lead ultimately to in(C) A.Ye. Demkovych flammatory and destructive lesions of periodontal tissues unresolved [5]. It is noted that in the process of chronic inflammation development with the destruction of periodontum and bone tissue, the immune response to microorganisms of the oral cavity is realised unstandard way. In the most cases, the process proceed on the setting of a low bactericidal potential of phagocytic cells, in particular mononuclear phagocytes, polyclonal activity of B-lymphocytes, high level of antibacterial antibodies and dysfunction of T-lymphocytes. At the same time, it is observed an increased granulation growth associated with disorder of proliferative processes, imbalance of cytokines production, and decrease of functional activity of phagocytic cells, induction of apoptosis with subsequent accelerated death and development of hypoergic inflammatory reaction $[6,7]$. 
Treatment of periodontitis is one of the urgent problems and require unordinary approaches to their solve. In this regard, the effectiveness of plant origin substances, which relate to polyphenolic compounds capable influence to the immune and inflammatory processes in the body are insufficiently studied. Quercetin (corvitin) belongs to flavonols with antioxidant, anti-ischemic, membranestabilizing and immunomodulatory properties $[8,9]$. It has a great redox potential and displays anti-inflammatory, anabolic, anti-apoptotic properties $[10,11]$.

The antioxidant activity of the drug with regard to its ability to suppress lipid peroxidation, to reduce the concentration of free radicals and toxic peroxidation products, to stimulate the catalase and superoxide dismutase activity of the organism. Anti-inflammatory and antiallergic effects also associated with the ability of corvitin to suppress calcium-ATPase and the synthesis of leukotrienes. Flavonol inhibits the activity of hyaluronidase and thus decrease vascular permeability, as well is able to increase the content of immune cells (phagocytosis, T-lymphocytes, B-lymphocytes), resulting to reduced manifestations of immunosuppression $[12,13]$.

The purpose of this study was to determine the effect of flavonol quercetin on the indices of the necrotic and apoptotic changes in neutrophil granulocytes and mononuclear phagocytes for the experimental bacterial-immune periodontitis development.

\section{METHODS}

The research was performed with the use of clinically healthy male white rats weighing $150-200 \mathrm{~g}$ in conditions of vivarium. The animals were in a standard diet, balanced by the main elements of nutrition. The investigation was conduced in conformity with the general rules and regulations of the "European Convention for the Protection of Vertebrate Animals Used for Experimental and Other Scientific
Purposes" (Strasbourg, 1986), and the "General Ethical Principles of Animal Experimentation" (Kyiv, 2001). Animals were divided into 3 groups: I - intact animals, control $(n=10)$; II - animals with experimental periodontitis on the 14th day of the study $(\mathrm{n}=8)$; III - animals with experimental periodontitis on the 14th day of the study, which was introduced quercetin (corvitin) $(n=8)$. These studies were performed in accordance with suggested and patented our pattern of experimental periodontitis [14], which reflects the role of bacterial and immune disorders in the mechanisms of inflammation development in the periodontal complex. Study of experimental periodontitis in that version and indices of bacterial-immune inflammation before were not investigated. Experimental periodontitis was produced in the animals by injection complex mixtures of microorganisms diluted in egg protein into periodontal tissues [15]. Simultaneously with introduction of the pathogen, a complete Freund's adjuvant was injected in the rat's paw to enhance the immune response. To the experimental animals of the third group was introduced intramuscular water soluble quercetin (corvitin, manufactured by the PJSC Borshchahivskiy CPP) in a dose $100 \mathrm{mg} /$ $\mathrm{kg}$ for 7 days (from the 7 th to the 14th day). On the 14th day of experiment, animals were killed by bleeding using thiopental anesthesia. For further research, the blood of the experimental animals was taken from which monocytes and neutrophil granulocytes were isolated by the method of gradient centrifugation [16]. FITClabeled annexin $\mathrm{V}$ from the ANNEXIN V FITC reagent kit (Beckman Coulter, USA) and propidium iodide (PI) was used to evaluate apoptosis and necrosis of granulocytes and monocytes using flow cytofluorometry [17]. In this case, monocytes (neutrophilic granulocytes), positive for PI and annexin V indicated a late stage of apoptosis or necrosis, and cells that were positive by annexin $V$ and negative by IP in the early stage of apoptosis. For apoptosis, cells are sent a signal, using phosphatidylserine (PS) through the extracellular membrane, to the phagocytes to 
purify the apoptotic cells. Aneksin V is explicitly linked to PS apoptotic cells. If apoptotic cells are not rapidly cleared by phagocytes, apoptotic cells may lose the integrity of the membrane and release their intracellular content (like necrosis). Late apoptosis will just happen during this process (secondary necrosis). The anxin $\mathrm{V}$ can bind to phosphatidylserine in apoptotic cells, whereas PI can stained the nucleus due to loss of membrane integrity [18]. The results were presented in percent (the ratio of the number of annexin-positive cells to the total fraction of neutrophils and phagocytes). The obtained results were statistically analyzed using the parametric and non-parametric statistical methods using the software Excel (Microsoft, USA) and STATISTICA 10.0 (Statsoft, USA) [19]. The reliability of the differences in the values between independent quantitative values was determined with a normal distribution according to the Mann-Whitney U criterion [20].

\section{RESULTS AND DISCUSSION}

Considering that mechanisms of inflammatory process formation in the periodontal tissues include a number of complicated pathogenetic links, we have chosen a bacterial-immune model, for which character of the disturbances was similar to human [21, 22].

The induced apoptosis of immune cells play important role in initiation, development and course of inflammation, from which depends the chacter of the pathological process and its outcome. There is a disturbance of the balance between proliferation, necrosis and apoptosis of mononuclear phagocytes and neutrophilic granulocytes in the inflammation of the periodontal tissues [23, 24].

The degree of necrosis and apoptosis of monocytes and neutrophils that changes under influence pathogen as well as regulatory factors is a key mechanism controlling development and prognostic consequence of inflammatory process in periodontal complex [25]. The indices of early apoptosis and late apoptosis / necrosis reflect the stage of apoptotic cells damage or complete death. Early apoptotic cells are Annexin V-positive and PI-negative (Annexin V-FITC ${ }^{+} / \mathrm{PI}$ ) indicates activation of caspases in the cellular cytoplasm, but the integrity of surface membrane is not affected. Late apoptosis / necrosis (end-stage) cells are Annexin V/ PI-double-positive (Annexin $\mathrm{V}$-FITC ${ }^{+} / \mathrm{PI}^{+}$) are also evidence of activation of caspases in the cellular cytoplasm, but there is a fragmentation of the surface membrane [26].

The results of our research shown that they occupy one of the key links in maintaining local immunity, and after expose to antigens necrosisapoptosis development in them.

It was important to compare the results of necrosis and apoptosis of blood mononuclear phagocytes and neutrophil granulocytes in the experimental model of the bacterial-immune periodontitis. In particular, studies have found that changes of total number cell dead and their correlation in the blood during of the inflammatory process in the periodontal complex were increased in relation to control.

Our study showed that during the formation of the inflammatory process in the tissues of the periodontal complex (second experimental group), which included the period until the $14^{\text {th }}$ day of the experiment, the total number of damaged neutrophil granulocytes significantly were increased (by 1.51 times; $\mathrm{P}<0.01$ ). At the same time, high level of cell death was conditioned mainly by neutrophils with signs of late apoptosis / necrosis, which exceeded the intact group by 1.72 times $(\mathrm{P}<0.01)$ (Figure 1 , Table 1). The level of cells with signs of early apoptosis was also significantly higher (by 1.45 times; $\mathrm{P}<0.01)$ as compared to control values (Figure 2).

Further studies showed that the total number of death blood mononuclear phagocytes for development of the inflammatory process in the periodontal complex also were increased in relation to the control values (Table 2 ).

Thus, the analysis of the results of necrotic and apoptotic changes in the monocytes on the 


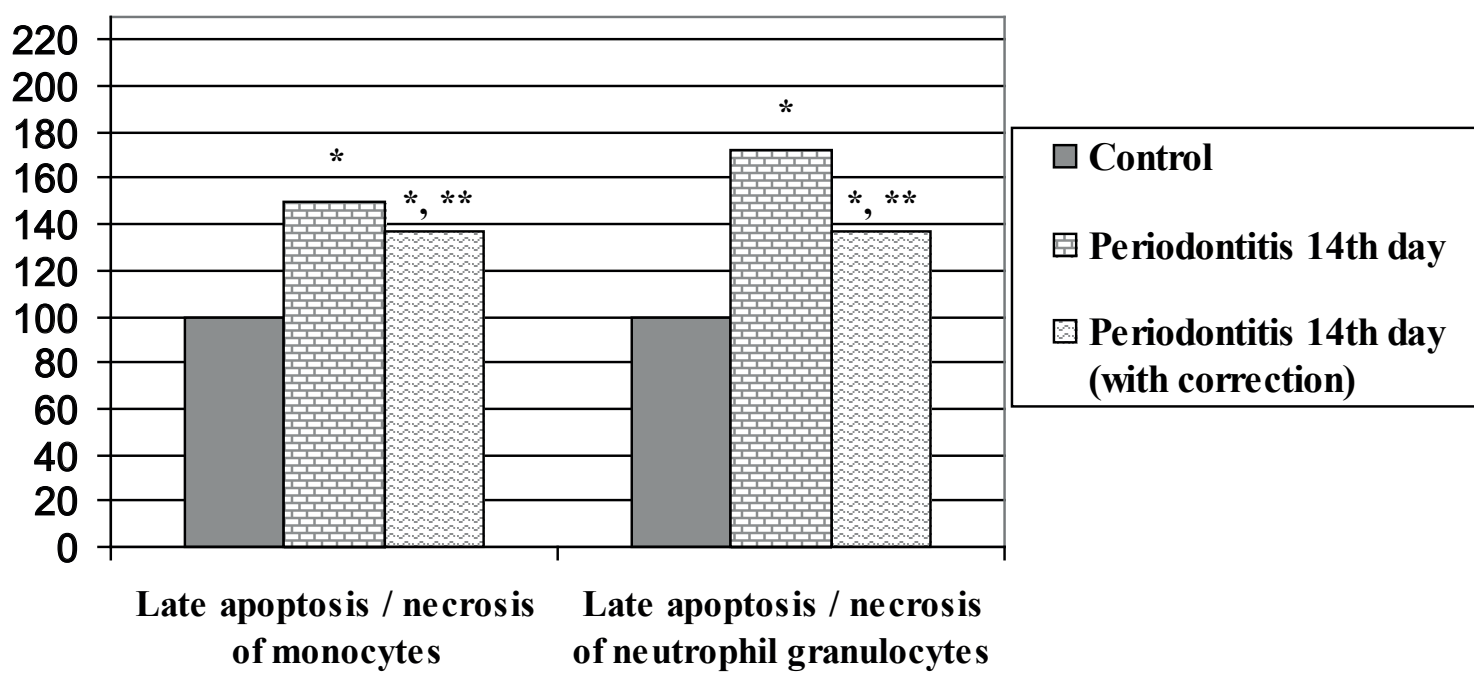

Fig. 1. The late apoptosis / necrosis dynamics of neutrophil granulocytes and monocytes in experimental periodontitis and with quercetin correction $(\%$ of control). Notes: $*$ - significant of differences in relation to the intact animals $(\mathrm{P}<0.01)$; ** - significant differences in relation to the animals with periodontitis on the $14^{\text {th }}$ day of the experiment $(\mathrm{P}<0.05)$

14th day of the research showed similar changes as in neutrophils, that is, the probable increase in the total number of dead cells in relation to the indices of the control group (by 1.51 times; $\mathrm{P}<0.01)$. At the same time, the induced death of mononuclear phagocytes was implemented due to both apoptosis (Figure 2) and necrosis (Figure 1),theirs levels exceeded the control values by $1.34(\mathrm{P}<0.01)$ and 1.50 times $(\mathrm{P}<0,01)$, respectively.

The results shown that the induced death of neutrophil granulocytes on the $14^{\text {th }}$ day of the

Table 1. Effects of quercetin to indices of necrotic and apoptotic changes in the neutrophil granulocytes of the blood rats with experimental bacterial-immune periodontitis $(M \pm m)$

\begin{tabular}{l|c|c|c|}
\hline \multirow{1}{*}{ Indices } & Control, intact & \multicolumn{2}{c|}{ Animals with experimental periodontitis } \\
animals & Without correction & $\begin{array}{c}\text { After correction with } \\
\text { quercetin }\end{array}$ \\
\hline Experiment duration (days) & - & 14 & 14 \\
Number of animals & 10 & 8 & 8 \\
Necrotic changed cells, \% & $1.62 \pm 0.05$ & $2.79 \pm 0.09$ & $2.21 \pm 0.13$ \\
Apoptotic changed cells, \% & $6.29 \pm 0.13$ & $\mathrm{P}_{1}<0.01$ & $\mathrm{P}_{1}<0.01 ; \mathrm{P}_{2}<0.05$ \\
& & $9.13 \pm 0.21$ & $7.64 \pm 0.25$ \\
Cells died, \% & $7.91 \pm 0.16$ & $\mathrm{P}_{1}<0.01$ & $\mathrm{P}_{1}<0.01 ; \mathrm{P}_{2}<0.01$ \\
& & $11.92 \pm 0.36$ & $9.85 \pm 0.35$ \\
Unchanged cells, \% & $92.09 \pm 0.16$ & $\mathrm{P}_{1}<0.01$ & $\mathrm{P}_{1}<0.01 ; \mathrm{P}_{2}<0.01$ \\
& & $88.08 \pm 0.36$ & $90.15 \pm 0.35$ \\
\end{tabular}

Notes (here and in table 2):

$\mathrm{P}_{1}$ - significant of differences in relation to intact animals;

$\mathrm{P}_{2}$ - significant of differences in relation to the animals with experimental periodontitis on the $14^{\text {th }}$ day of the research without correction. 


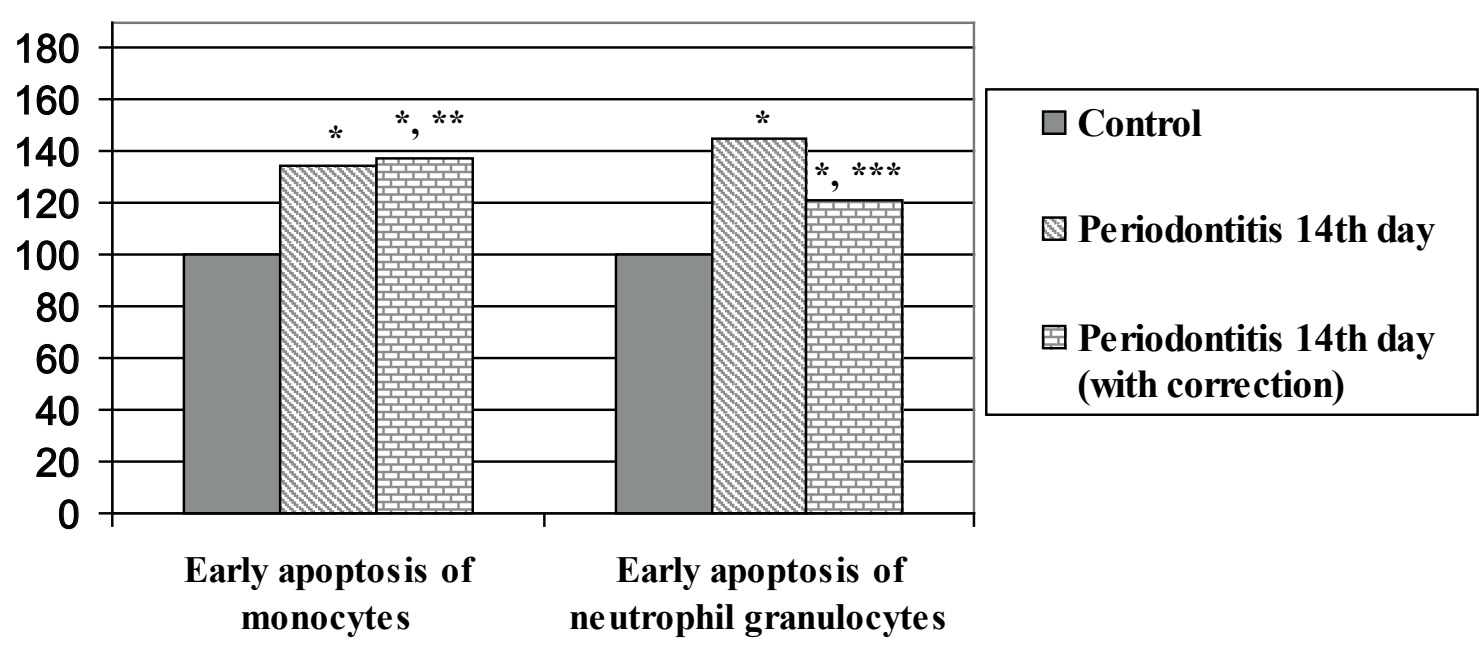

Fig. 2. The early apoptosis dynamics of neutrophil granulocytes and monocytes in experimental periodontitis and quercetin correction ( $\%$ of control). Notes: * - significant of differences in relation to the intact animals $(\mathrm{P}<0.01)$; ** - significant differences in relation to the animals with periodontitis on the $14^{\text {th }}$ day of the experiment $(\mathrm{P}<0.01)$, *** - significant differences in relation to the animals with periodontitis on the $14^{\text {th }}$ day of the experiment $(\mathrm{P}<0.05)$

study after use of flavonol quercetin for 7 days occurred as a result both necrosis and apoptosis, theirs means exceeded the control value.

The analysis of annexin-positive blood neutrophil granulocytes level (early apoptosis) after using of quercetin shown a significant decrease in their level on the $14^{\text {th }}$ day without correction - by 1.20 times $(\mathrm{P}<0.01)$. However, these indices remained at a high level as compared to the control group indices, that is, they were higher - by 1.22 times $(\mathrm{P}<0.01)$ (Figure 2$)$.

Comparing the level of neutrophils with signs of late apoptosis / necrosis, it should be noted that on the $14^{\text {th }}$ day of the study (with a correction ) their number significantly was decreased (by 1.26 times; $\mathrm{P}<0.05$ ) in relation to the data obtained for the same investigated period, but without the introduction of flavonol (Figure 1). At the same time, comparing the indices on the $14^{\text {th }}$ day of the experimental

Table 2. Effects of quercetin to indices of necrotic and apoptotic changes in the monocytes of the blood rats with experimental bacterial-immune periodontitis $(\mathbf{M} \pm \mathbf{m})$

\begin{tabular}{|c|c|c|c|}
\hline \multirow[b]{2}{*}{ Indices } & \multirow{2}{*}{$\begin{array}{l}\text { Control, intact } \\
\text { animals }\end{array}$} & \multicolumn{2}{|c|}{ Animals with experimental periodontitis } \\
\hline & & Without correction & $\begin{array}{l}\text { After correction with } \\
\text { quercetin }\end{array}$ \\
\hline Experiment duration (days) & - & 14 & 14 \\
\hline Number of animals & 10 & 8 & 8 \\
\hline Necrotic changed cells, $\%$ & $0.95 \pm 0.02$ & $1.42 \pm 0.07$ & $1.30 \pm 0.07$ \\
\hline Apoptotic changed cells, $\%$ & $5.00 \pm 0.02$ & $\begin{array}{c}\mathrm{P}_{1}<0.01 \\
6.72 \pm 0.03 \\
\mathrm{P}_{1}<0.01\end{array}$ & $\begin{array}{c}\mathrm{P}_{1}<0.01 ; \mathrm{P}_{2}<0.05 \\
\quad 6.87 \pm 0.03 \\
\mathrm{P}_{1}<0.01 ; \mathrm{P}_{2}<0.05\end{array}$ \\
\hline Cells died, \% & $5.95 \pm 0.03$ & $\begin{array}{c}8.14 \pm 0.07 \\
\mathrm{P}_{1}<0.01\end{array}$ & $\begin{array}{c}8.17 \pm 0.07 \\
\mathrm{P}_{1}<0.01 ; \mathrm{P}_{2}>0.05\end{array}$ \\
\hline Unchanged cells, $\%$ & $94.05 \pm 0.03$ & $\begin{array}{c}91.86 \pm 0.07 \\
\mathrm{P}_{1}<0.01\end{array}$ & $\begin{array}{c}91.83 \pm 0.07 \\
\mathrm{P}_{1}<0.01 ; \mathrm{P}_{2}>0.05\end{array}$ \\
\hline
\end{tabular}


periodontitis with correction, it remained higher (by 1.36 times; $\mathrm{P}<0.01$ ) than the indices of the control animals.

It should be noted that amount of annexinpositive mononuclear phagocytes (early apoptosis) in the blood of experimental animals of this group was found a decreased (by 1.02 times; $\mathrm{P}<0.05$ ) as compared with animals, which were investigated on the $14^{\text {th }}$ day of the experiment (Figure 2), but their level remained higher in relation to control (by 1.37 times; $\mathrm{P}<0.01$ ).

At the same time, on analysis of late apoptosis / necrosis of monocytes in the second and third groups of experimental animals, it was found that level of necrotized monocytes in the group of animals with correction was lower (by 1.09 times; $\mathrm{P}<0.05$ ) as compared to indices of animals, which were investigated on the $14^{\text {th }}$ day without correction by flavonol (Figure 1), however they were found significantly higher in relation to control (by 1.37 times; $\mathrm{P}<0.01$ ).

Thus, flavonol quercetin proved to weaken unadequate the immune response, to reduce destructive processe, to suspend and stabilize the further development of the inflammation connected with this pathology.

\section{CONCLUSION}

1. The development and the course of experimental periodontitis is accompanied by an increase content of annexin-positive (early apoptosis) and necrotized mononuclear phagocytes and neutrophilic granulocytes in the blood, that is associated with strengthening of destructive processes in the periodontal complex, their formation owing to antigen stimulation and regulatory mechanisms.

2. Flavonol quercetin reduces amount of blood monocytes and neutrophilic granulocytes with signs of cell death in the experimental bacterial-immune periodontitis, in this manner stabilizes and attenuates inflammation.

The authors of this study confirm that the research and publication of the results were not associated with any conflicts regarding commercial or financial relations, relations with organizations and/or individuals who may have been related to the study, and interrelations of co-authors of the article.

\section{А.Є. Демкович}

\section{НЕКРОЗО-АПОПТИЧНІ ЗМІНИ У НЕЙТРО- ФІЛАХ І МОНОЦИТАХ КРОВІ ПРИ ЕКСПЕРИМЕНТАЛЬНОМУ ПАРОДОНТИТІ ТА КОРЕКЦІЯ ЇХ КВЕРЦЕТИНОМ}

Мета дослідження полягала у визначенні вмісту апоптично змінених і некротизованих мононуклеарних фагоцитів та нейтрофільних гранулоцитів крові в процесі розвитку експериментального бактеріально-імунного пародонтиту та при корекції його кверцетином (корвітином). У статті наведено результати досліджень показників раннього та пізнього апоптозу моноцитів та нейтрофілів крові на 14-ту добу розвитку запального процесу в тканинах пародонта, а також можливість корекції їх під впливом кверцетину. У тварин відбирали кров, з якої виділяли моноцити та нейтрофіли методом градієнтного центрифугування. Оцінку апоптозу та некрозу проводили методом проточної лазерної цитофлуориметрії. При цьому виявлена характерна динаміка кількості загиблих клітин у процесі формування запального вогнища у пародонтальному комплексі. Зокрема, перебіг експериментального пародонтиту супроводжувався підвищенням вмісту анексинпозитивних (ранній апоптоз) моноцитів і нейтрофілів крові на 14-ту добу, що пов'язано з посиленням інтенсивності запального процесу та їх утворенням у відповідь на антигену стимуляцію. Показники пізнього апоптозу / некрозу у цей період також перевищували контрольні значення. Застосування кверцетину (внутрішньом'язово в дозі 100 мг/кг) зменшувало кількість мононуклеарних фагоцитів та нейтрофільних гранулоцитів крові з ознаками клітинної загибелі та покращувало перебіг запального процесу.

Ключові слова: бактеріально-імунний пародонтит; мононуклеарні фагоцити; нейтрофільні гранулоцити; апоптоз; некроз; кверцетин.

ДВНЗ «Тернопільський державний медичний університет імені І. Я. Горбачевського МОЗ Украӥни»

\section{А.Е. Демкович \\ НЕКРОТИЧЕСКО-АПОПТИЧЕСКИЕ ИЗМЕ- НЕНИЯ В НЕЙТРОФИЛАХ И МОНОЦИТАХ КРОВИ ПРИ ЭКСПЕРИМЕНТАЛЬНОМ БАК- ТЕРИАЛЬНО-ИММУННОМПАРОДОНТИТЕ И КОРРЕКЦИЯ ИХ КВЕРЦЕТИНОМ}

Цель исследования заключалась в определении содержания апоптически измененных и некротизированных моно- 
нуклеарных фагоцитов и нейтрофилов крови в процессе развития экспериментального бактериально-иммунного пародонтита и при коррекции его кверцетином (корвитином). В статье приведены результаты исследований показателей раннего и позднего апоптоза моноцитов и нейтрофилов крови на 14-е сутки развития воспалительного процесса в тканях пародонта, а также возможность коррекции их под влиянием кверцетина (корвитина). У животных отбирали кровь, из которой выделяли моноциты и нейтрофилы методом градиентного центрифугирования. Оценку апоптоза и некроза проводили методом проточной лазерной цитофлуориметрии. При этом выявлена характерная динамика изменений количества погибших клеток в процессе формирования воспалительного очага в пародонтальном комплексе. В частности, ход экспериментального пародонтита сопровождался повышением содержания аннексинположительных (ранний апоптоз) моноцитов и нейтрофилов крови на 14-е сутки, что связано с усилением интенсивности воспалительного процесса и их образованием в ответ на антигенную стимуляцию. Показатели позднего апоптоза / некроза в этот период также превышали контрольные значения. Применение кверцетина (внутримышечно в дозе 100 мг / кг) уменьшало количество мононуклеарных фагоцитов и нейтрофилов крови с признаками клеточной гибели и улучшало течение воспалительного процесса.

Ключевые слова: бактериально-иммунный пародонтит; мононуклеарные фагоциты; нейтрофильные гранулоциты; апоптоз; некроз; кверцетин.

\section{REFERENCES}

1. Bayani M, Pourali M, Keivan M. Possible interaction between visfatin, periodontal infection, and other systemic diseases: A brief review of literature. Eur J Dent. 2017; 11(3): 407-10.

2. Arimatsu K, Yamada H, Miyazawa H, Minagawa $T$, Nakajima M, et al. Oral pathobiont induces systemic inflammation and metabolic changes associated with alteration of gut microbiota. Sci Rep. 2014; 6(4): 4828.

3. Colombo NH, Shirakashi DJ, Chiba FY, Coutinho MS, Ervolino E, et al. Periodontal disease decreases insulin sensitivity and insulin signaling. J Periodontol. 2012; 83(7): 864-70.

4. Li Y, Lu Z, Zhang X, Yu H, Kirwood KL, et al. Metabolic syndrome exacerbates inflammation and bone loss in periodontitis. J Dent Res. 2015; 94(2): 362-70.

5. Srivastava N, Nayak PA, Rana S. Point of Care-A Novel Approach to Periodontal Diagnosis - A Review. J Clin Diagn Res. 2017; 11(8): ZE01-ZE06.

6. Kozak DV, Hudyma AA. Influence of polytrauma on the dynamics of late apoptosis of tissue lymphocytes. Clinical Surgery. 2013; 9: 70-2. [Ukrainian].

7. Shmarov DA, Pogorelov VM, Kozinets HI. Modern aspects of evaluation of proliferation and apoptosis in clinical laboratory diagnostics (review of literature). Clin
Lab Diagn. 2013; 1: 36-9. [Russian].

8. D'Andrea G. Quercetin: A flavonol with multifaceted therapeutic applications? Fitoterapia. 2015; 106: 256-71.

9. Miles SL, McFarland M, Niles RM. Molecular and physiological actions of quercetin: need for clinical trials to assess its benefits in human disease. Nutrition Reviews. 2014; 72(11): 720-34.

10. Kravets BB, Regeda MS. The role of corvitin in the correction of violations of lipid peroxidation processes and the activity of the antioxidant system in guinea pigs blood in experimental bacterial keratitis against the background of bronchial asthma and pneumonia. Med and Clin Chemistry. 2015; 17(2): 69-71. [Ukrainian].

11. Mikhailova YA, Kravchun PH, Petyunina OV, Lapshyna LA. The influence of cardioprotection on the state of hemodyncmics at treatment of cardiorenal syndrome in patients with chronic heart failure and chronic kidney disease. Int Med J. 2013; 19(1): 44-9. [Russian].

12. Posokhova KA, Stechyshyn IP, Pidhirnyy VV. Influence of corvitin-containing compounds on myocardium status in diabetes mellitus type 2. J Achievements of Clin and Exper Med. 2014; 2: 17-21. [Ukrainian].

13. Demkovych A, Bondarenko Yu, Hasiuk P. Humoral immune reactivity disorders in experimental parodontitis and their correction by flavonol. World of Medicine and Biology. 2017; 3(61): 97-100.

14. Demkovych AY, Bondarenko YI, inventor; I. Horbachevsky Ternopil State Medical Univ., assignee. Pathogenetic basis periodontitis modeling in rats. Ukraine patent 82388 u201303000. 2013 Jul 25.

15. Demkovych AY, Bondarenko YI. Pathogenetic basis periodontitis modeling in rats. Achiev of Clin and Exper Med. 2015; 1(22): 54-7. [Ukrainian].

16. Looney MR, Matthay MA. Neutrophil sandwiches injure the microcirculation. Nat Med. 2009; 4(15): 364-6.

17. Maianski NA, Maianski AN, Kuijpers TW, Roos D. Apoptosis of neutrophils. Acta Haematol. 2004; 1-2(111): 56-66.

18. Wlodkowic D, Telford W, Skommer J, Darzynkiewicz Z. Apoptosis and beyond: cytometry in studies of programmed cell death. Methods Cell Biol. 2011; 103: 55-98.

19. Orlov A. Cases Mathematics, Probability and Statistics Basic facts. Moscow: MZ-Press; 2004. [Russian].

20. Berger RL, Casella G. Statistical Inference. 2nd ed. Florida: Duxbury Press; 2001.

21. Demkovych A, Bondarenko Yu, Hasiuk PA. Oxidative modification of proteins in the process of experimental periodontitis development. Interv Med Appl Sci. 2017; 9(4): 218-221.

22. Demkovych AYe, Bondarenko YuI. Changes of antioxidant potential under the experimental periodontitis development. Fiziol Zh. 2018, 3(64): 43-51.

23. Jia SH, Parodo J, Charbonney E, Tsang JL, Jia SY, Rostein OD, et al. Activated neutrophils induce epithelial cell apoptosis through oxidant-dependent tyrosine dephosphorylation of caspase-8. Am J Pathol. 2014; 4(184): 1030-40. 
24. Srinivas M, Chethana KC, Padma R, Suraqimath G, Anil M, Pai BS, et al. A study to assess and compare the peripheral blood neutrophil chemotaxis in smokers and non smokers with healthy periodontium, gingivitis, and chronic periodontitis. J Indian Soc Periodontol. 2012; 16: $54-8$.

25. Demkovych AYe. The necrotic-apoptotic changes in blood mononuclear phagocytes in the experimental bacterialimmune periodontitis development. World of Medicine and Biology. 2018; 1(63): 120-2.

26. Kudryavtsev IV, Golovkin AS, Zurochka AV, Khaydukov SV. Modern methods and approaches to the study of apoptosis in experimental biology. Med Immun. 2012; 6(14): 461-82. [Russian]. 